\title{
Activity in vitro of ten antimicrobial agents against Neisseria gonorrhoeae A study of the correlation between the sensitivities
}

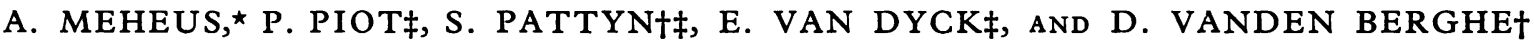 \\ From the Department of Epidemiology and Social Medicine ${ }^{\star}$, and the Department of Microbiologyt, \\ Antwerp University, and the ènstitute of Tropical Medicineł, Antwerp, Belgium
}

\section{Summary}

I05 Belgian strains of Neisseria gonorrhoeae were tested for their sensitivity to penicillin, ampicillin, rifampicin, erythromycin, tetracycline, streptomycin, spectinomycin, sulphamethoxazole, trimethroprim, and a combination of sulphamethoxazole and trimethroprim in a 5:1 ratio. Distribution and median values of minimum inhibitory concentrations (MICs) are given and discussed. 42 per cent. of strains were relatively resistant to penicillin (MIC $\geqq 0.04 \mu \mathrm{g} / \mathrm{ml}$.), but only 2 per cent. showed high-level resistance (MIC $\geqq 0.38 \mu \mathrm{g} / \mathrm{ml}$.), which is comparable with the prevalence of decreased sensitivity found in other European countries.

A significant positive correlation ( $P \leqq 0.01$, rank correlation coefficient) is found between the sensitivities to penicillin, ampicillin, erythromycin, tetracycline, and streptomycin, except for the ampicillin-erythromycin and ampicillin-tetracycline pairs. Rifampicin is correlated with tetracycline. No correlation is found between the sensitivities to spectinomycin and any of the other drugs.

The combination of sulphamethoxazole and trimethoprim in a 5:I ratio also shows a significant positive correlation with penicillin and ampicillin and with sulphamethoxazole and trimethoprim separately.

\section{Introduction}

Quantitative determinations of the sensitivity of Neisseria gonorrhoeae to penicillin and various other antibiotics have never, so far as we know, been published for Belgium. Numerous publications on this subject have appeared in the last 15 years, especially in the English language, and these have been excellently reviewed (Sparling, 1972). Most of the authors noted strong positive correlations between the sensitivities of gonococcal strains to various antibacterial agents, such as penicillin, ampicillin, erythromycin, spiramycin, tetracycline, streptomycin, fusidic acid and rifampicin (Reyn and Bentzon, 1968 and 1969; Phillips, Rimmer, Ridley, Lynn, and Warren, 1970, Maness and Sparling, 1973; Givan and Keyl, 1974; Stolz, Zwart, and Michel, 1974 ; Maier, Beilstein, and Zubrzycki, 1974). The hypothesis that a common genetic basis is responsible for resistance to multiple antibacterial agents (Maness and Sparling, 1973) indicated a need for more knowledge of the genetics and biochemistry of the antibiotic resistance of the gonococcus and recently, linked genetic loci of resistance have been determined (Sarubbi, Blackman, and Sparling, 1974; Maier, Zubrzycki, and Coyle, 1975). Taking into account the lack of data for Belgium, we conducted a study with the following aims:

(a) to describe the range of sensitivities of $N$. gonorrhoeae to ten antibacterial agents and to compare the data with those for other countries;

(b) to analyse correlations between the sensitivities to the different antibacterial agents;

(c) to draw conclusions for the rational use of antibiotics in the treatment of gonorrhoea.

\section{Material and methods}

Strains, media, and techniques

105 unselected strains of $N$. gonorrhoeae from Antwerp (93 strains) and from Leuven and Gent (12 strains) were collected between March, 1974, and February, 1975, and were preserved by lyophilization. 85 per cent. were obtained from male patients.

Isolation was performed on the selective medium blood agar saponin (BAS) (DST agar-oxoid +1 per cent. saponin +5 per cent. horse blood+VCN-inhibitor : Thayer and Martin, 1966). Identification was based on colonial morphology, Gram stain, and growth enhancement in a 10 per cent. $\mathrm{CO}_{2}$ enriched atmosphere; each strain was tested for oxidase and beta-galactosidase 
activity, and fermentation of glucose, maltose, sucrose, and lactose.

Sensitivity to penicillin, ampicillin, erythromycin, rifampicin, tetracycline, streptomycin, spectinomycin, sulphamethoxazole, trimethoprim, and a combination of sulphamethoxazole and trimethoprim in the ratio 5:1 were determined by the agar dilution method. National standards of benzyl penicillin, ampicillin, erythromycin, rifampicin, streptomycin, and tetracycline were provided by the Laboratorium voor Standaarden en Farmacopee, Ministerie van Volksgezondheid, Brussels. Sulphamethoxazole and trimethoprim were supplied by Roche and spectinomycin by Upjohn, Belgium.

With a multipoint replicator, suspensions from overnight cultures in $5 \mathrm{ml}$. blood saponin broth (Tryptic Soy Broth (Difco 0370) +1 per cent. saponin (Merck 7695) + 5 per cent. horse blood) were inoculated on to plates containing the antibiotics (DST agar (Oxoid CM261) + 1 per cent. saponin (Merck 7695) +5 per cent. horse blood). The inoculum was $10^{4}$ colony forming units (CFU). Control plates without antibiotics were inoculated as the first and last plates in each series. After incubation for $48 \mathrm{hrs}$, the minimum inhibitory concentration (MIC) was determined as the lowest concentration of each antibiotic in which bacterial growth was completely inhibited, or the growth of a maximum of ten colonies occurred.

In each experiment, W.H.O. N. gonorrhoeae referencestrains III, V, and VII (A. Reyn, Statens Seruminstitut, Kopenhagen) and Staphylococcus aureus (NCTC 6571) were included.

Penicillin-sensitivity of Reyn's reference strains is expressed as Inhibitory Concentration 50 per cent. (IC 50). The MIC is defined as $2 \times I C 50$.
During the investigation the MIC for penicillin of the reference strains was tested eight times with the following results: Reyn III: four times $0.10 \mu \mathrm{g} . / \mathrm{ml}$. and four times $0.05 \mu \mathrm{g} . / \mathrm{ml}$. (IC $50=0.069$ ) Reyn V: six times $0.19 \mu \mathrm{g} . / \mathrm{ml}$. and twice $0.10 \mu \mathrm{g} . / \mathrm{ml}$. (IC $50=0.55$ ) Reyn VII: eight times $0.01 \mu \mathrm{g} . / \mathrm{ml}$. (IC $50=0.0089$ ) Staph. aureus NCTC 6571: eight times $0.02 \mu \mathrm{g} . / \mathrm{ml}$.

Statistical methods

The results were put on magnetic tape and analysed with a Hewlett Packard 9820 A-model 30 desk computer. The distribution of MICs for each antibiotic was summarized by its median value.

Rank correlation coefficients were determined with Spearman's rank correlation test. The 1 per cent. and 0.1 per cent. levels of significance are indicated.

\section{Results}

Table I gives the range of MICs for each antibacterial agent tested. MICs for penicillin and ampicillin show the well-known bimodal distribution with the first modus at $0.01 \mu \mathrm{g} . / \mathrm{ml}$. and the second at $0.1 \mu \mathrm{g} . / \mathrm{ml}$. for ampicillin, and at $0.01 \mu \mathrm{g} . / \mathrm{ml}$. and $0.19 \mu \mathrm{g} . / \mathrm{ml}$. for penicillin. About $42 \mathrm{per}$ cent. of the 105 strains have a MIC for penicillin in the range of 0.05 to $0.38 \mu \mathrm{g} . / \mathrm{ml}$. and are relatively resistant. 38 per cent. of the strains are relatively resistant for ampicillin (MIC $\geqq 0.16 \mu \mathrm{g} . / \mathrm{ml}$.). If we divide the strains less sensitive to penicillin in groups of 'low-level' and 'high-level' resistance (MIC $\geqq 0.38 \mu \mathrm{g} . / \mathrm{ml}$.), only 2 per cent. of strains

TABLE I Distribution and median values of MICs of ten antibacterial agents for 105 strains of $\mathrm{N}$. gonorrhoeae

\begin{tabular}{|c|c|c|c|c|c|c|c|c|c|c|}
\hline \multirow[t]{2}{*}{ Antibacterial agent } & \multirow{2}{*}{$\begin{array}{l}\text { Median value } \\
\text { of } M I C \\
(\mu g . / m l .)\end{array}$} & \multicolumn{9}{|c|}{ Number of strains with MICs ( $\mu g$. per ml.) } \\
\hline & & 0.003 & 0.006 & 0.012 & 0.024 & 0.048 & 0.096 & 0.19 & 0.38 & $\geqq 0.78$ \\
\hline \multirow[t]{2}{*}{$\begin{array}{l}\text { Penicillin } \\
\text { Ampicillin } \\
\text { Erythromycin } \\
\text { Rifampicin }\end{array}$} & $\begin{array}{l}0.029 \\
0.033 \\
0.035 \\
0.195\end{array}$ & $\begin{array}{l}- \\
- \\
-\end{array}$ & $\begin{array}{r}11 \\
1 \\
-\end{array}$ & $\begin{array}{l}35 \\
42 \\
11 \\
-\end{array}$ & $\begin{array}{l}15 \\
16 \\
55 \\
-\end{array}$ & $\begin{array}{r}9 \\
6 \\
24 \\
4\end{array}$ & $\begin{array}{l}15 \\
32 \\
11 \\
39\end{array}$ & $\begin{array}{r}18 \\
8 \\
1 \\
46\end{array}$ & $\frac{2}{3}$ & $\begin{array}{c}- \\
- \\
-\end{array}$ \\
\hline & & $0 \cdot 19$ & $0 \cdot 39$ & $0 \cdot 78$ & $1 \cdot 56$ & $3 \cdot 1$ & $6 \cdot 2$ & $12 \cdot 5$ & 25 & $\geqq 50$ \\
\hline \multirow[t]{2}{*}{$\begin{array}{l}\text { Tetracycline } \\
\text { Streptomycin }\end{array}$} & $\begin{array}{l}0.59 \\
5 \cdot 58\end{array}$ & - & 38 & 29 & $\underline{38}$ & $-\overline{9}$ & $\overline{55}$ & $\overline{21}$ & - & $\overline{20}$ \\
\hline & & & $2 \cdot 5$ & 5 & 10 & 15 & & & & \\
\hline \multirow[t]{2}{*}{ Spectinomycin } & $5 \cdot 94$ & - & 41 & 64 & 一 & & & & & \\
\hline & & $\leqq 1$ & 2 & 4 & 8 & 16 & 32 & 64 & $\geqq 128$ & \\
\hline \multirow[t]{2}{*}{$\begin{array}{l}\text { Sulphamethoxazole } \\
\text { Trimethoprim }\end{array}$} & $\begin{array}{l}20 \cdot 44 \\
18 \cdot 17\end{array}$ & 2 & 4 & 6 & $\begin{array}{r}13 \\
3\end{array}$ & $\begin{array}{l}23 \\
42\end{array}$ & $\begin{array}{l}18 \\
59\end{array}$ & $\begin{array}{c}18 \\
1\end{array}$ & 21 & \\
\hline & & $\leqq 1^{\mathrm{a}}$ & $2^{\mathrm{a}}$ & $4^{\mathrm{a}}$ & $8^{a}$ & $\geqq 16^{\mathrm{a}}$ & & & & \\
\hline $\begin{array}{l}\text { Combination of } \\
\text { sulphamethoxazole plus } \\
\text { trimethoprim in } 5: 1 \\
\text { ratio }\end{array}$ & 2.96 & 7 & 24 & 46 & 25 & 3 & & & & \\
\hline
\end{tabular}

a $\mu \mathrm{g} . / \mathrm{ml}$. of the mixture 
have high level resistance to penicillin. The MICs for streptomycin also show a bimodal distribution with 19 per cent. of strains highly resistant.

All MIC values for spectinomycin fall in the range of 2.5 to $5 \mu \mathrm{g} . / \mathrm{ml}$. Median values of MICs are comparable for sulphamethoxazole and trimethoprim, but their distribution is much wider for sulphamethoxazole. There is a great reduction in MIC when sulphamethoxazole and trimethoprim are used together in a 5:1 ratio.

Table II shows the 45 rank correlation coefficients between MICs for ten antibacterial agents (including MICs of sulphamethoxazole and trimethoprim in a 5:1 ratio).

A significant positive correlation $(P \leqq 0.01)$ is found between sensitivities of penicillin, ampicillin, erythromycin, tetracycline, and streptomycin, except for the ampicillin-erythromycin and ampicillintetracycline pairs. Rifampicin is significantly correlated with erythromycin. No correlation is found between sensitivities to spectinomycin and any of the other drugs. Sulphamethoxazole is significantly correlated with penicillin and ampicillin.

The sensitivities to a combination of sulphamethoxazole and trimethoprim show a significant positive correlation with penicillin and ampicillin, and of course also with sulphamethoxazole and trimethoprim separately.

Considering the drugs paired with penicillin, the highest correlation is found with ampicillin, followed by streptomycin, sulphamethoxazole, the combination sulphamethoxazole and trimethoprim, erythromycin, trimethoprim, and tetracycline.

Considering ampicillin, the results are almost identical with those for penicillin, except for a lower correlation with erythromycin and tetracycline.

Table III gives the prevalence of decreased sensitivity to penicillin of $N$. gonorrhoeae in different countries. Our results are comparable with the figures found in England, the Netherlands, and Australia, but much lower than the prevalence of decreased sensitivity found in Canada and the

TABLE II Rank correlation coefficients between MICs for ten antibacterial agents for 105 strains of $\mathrm{N}$. gonorrhoeae

\begin{tabular}{|c|c|c|c|c|c|c|c|c|c|}
\hline Antibacterial agent & $\begin{array}{l}\text { Peni- } \\
\text { cillin }\end{array}$ & $\begin{array}{l}\text { Ampi- } \\
\text { cillin }\end{array}$ & $\begin{array}{l}\text { Rifam- } \\
\text { picin }\end{array}$ & $\begin{array}{l}\text { Erythro- } \\
\text { mycin }\end{array}$ & $\begin{array}{l}\text { Tetra- } \\
\text { cycline }\end{array}$ & $\begin{array}{l}\text { Strepto- } \\
\text { mycin }\end{array}$ & $\begin{array}{l}\text { Spectino- } \\
\text { mycin }\end{array}$ & $\begin{array}{l}\text { Sulpha- } \\
\text { methoxazole }\end{array}$ & $\begin{array}{l}\text { Trimetho- } \\
\text { prim }\end{array}$ \\
\hline \multicolumn{10}{|l|}{ Penicillin } \\
\hline Ampicillin & $0.88^{b}$ & & & & & & & & \\
\hline Rifampicin & 0.23 & $0 \cdot 23$ & & & & & & & \\
\hline Erythromycin & $0.41^{b}$ & $0 \cdot 21$ & $0.51^{b}$ & & & & & & \\
\hline Tetracycline & $0 \cdot 26^{\mathrm{a}}$ & 0.19 & 0.08 & $0 \cdot 27^{\mathrm{a}}$ & & & & & \\
\hline Streptomycin & $0.56^{\mathrm{b}}$ & $0.52^{\mathrm{b}}$ & 0.18 & $0.33^{b}$ & $0 \cdot 31^{\mathrm{a}}$ & & & & \\
\hline Spectinomycin & 0.04 & $0 \cdot 24$ & -0.17 & -0.34 & 0.02 & $0 \cdot 12$ & & & \\
\hline Sulphamethoxazole & $0.43^{b}$ & $0.43^{b}$ & 0.17 & $0 \cdot 12$ & $0 \cdot 19$ & $0 \cdot 20$ & -0.02 & & \\
\hline Trimethoprim & $0 \cdot 28^{\mathrm{a}}$ & 0.23 & 0.09 & $0 \cdot 12$ & $0.34^{b}$ & 0.01 & -0.11 & $0.65^{b}$ & \\
\hline \multicolumn{10}{|l|}{ Sulphamethoxazole + Trimetho- } \\
\hline prim & $0.42^{\mathrm{b}}$ & $0.41^{\mathrm{b}}$ & 0.19 & 0.12 & 0.20 & 0.16 & 0.01 & $0.86^{b}$ & $0.63^{b}$ \\
\hline
\end{tabular}

aP $\leqq 0.01 \quad$ bP $\leqq 0.001$

TABLE II I Penicillin sensitivity of N. gonorrhoeae in different countries

\begin{tabular}{|c|c|c|c|c|c|c|}
\hline \multirow{2}{*}{\multicolumn{2}{|c|}{ Source }} & \multirow{3}{*}{ Country } & \multirow{3}{*}{$\begin{array}{l}\text { Year of } \\
\text { study }\end{array}$} & \multirow{3}{*}{$\begin{array}{l}\text { No. of } \\
\text { strains }\end{array}$} & \multicolumn{2}{|c|}{ Decreased sensitivity } \\
\hline & & & & & Prevalence & Criterion of \\
\hline Authors & Date & & & & (per cent.) & $M I C$ \\
\hline \multicolumn{7}{|l|}{ Martin, Lester, Price, and } \\
\hline Schmale & 1970 & USA & $1950-55$ & 721 & 1 & $\geqq 0.10 \mathrm{IU} / \mathrm{ml}$ \\
\hline Martin and others & 1970 & USA & 1965 & 1,124 & 42 & $\geqq 0.10 \mathrm{IU} / \mathrm{ml}$ \\
\hline Martin and others & 1970 & USA & 1968 & 649 & 65 & $\geqq 0.10 \mathrm{IU} / \mathrm{ml}$ \\
\hline Amies & 1969 & Canada & 1967 & 1,976 & 54 & $\geqq 0.10 \mathrm{IU} / \mathrm{ml}$. \\
\hline Maness and Sparling & 1973 & USA & 1971 & 147 & 69 & $\geqq 0.06 \mu \mathrm{g} . / \mathrm{ml}$ \\
\hline Phillips and others & 1970 & England & $1968-69$ & 96 & 40 & $\geqq 0.06 \mu \mathrm{g} . / \mathrm{ml}$ \\
\hline Stolz and others & 1974 & Netherlands & $1971-72$ & 258 & 38 & $\geqq 0.048 \mu \mathrm{g} . / \mathrm{ml}$. \\
\hline Present study & 1976 & Belgium & 1974 & 105 & 42 & $\geqq 0.08 \mathrm{IUU} / \mathrm{ml}$ \\
\hline Smithurst & 1974 & Australia & 1972 & 199 & 31 & $\geqq 0.125 \mathrm{IU} / \mathrm{ml}$. \\
\hline Panikabutra and Suvanmalik & 1973 & Thailand & $1967-70$ & 96 & 77 & $\geqq 0.128 \mathrm{IU} / \mathrm{ml}$. \\
\hline Hart & 1973 & South Vietnam & 1970 & 100 & 99 & $\geqq 0.10 \mathrm{IU} / \mathrm{ml}$. \\
\hline Watko and Brownlow & 1975 & Philippines & 1971 & 258 & 91 & $\geqq 0.10 \mathrm{IU} / \mathrm{ml}$ \\
\hline Arya and Phillips & 1970 & Uganda & 1968 & 173 & 82 & $\geqq 0.06 \mu \mathrm{g} . / \mathrm{ml}$ \\
\hline Plorde, Kidan, and Wright & 1973 & Ethiopia & $1969-70$ & 234 & 50 & $\geqq 0.075 \mu \mathrm{g} . / \mathrm{ml}$. \\
\hline Meheus, unpublished & & Rwanda & 1975 & 22 & 86 & $\geqq 0.048 \mu \mathrm{g} . / \mathrm{ml}$. \\
\hline
\end{tabular}

The series reported are comparable, if we consider the formula : $0.6 \mu \mathrm{g} .=1$ Unit penicillin G. 
United States. Decreased sensitivity to penicillin is highly prevalent in most African countries and in South-East Asia, with a range from 77 to 99 per cent.

\section{Discussion}

Alternative treatment schedules to penicillin and ampicillin are used more and more for gonorrhoea. The major indications for these alternatives are treatment failures due to an infection with relatively resistant strains, or hypersensitivity to penicillin. In Belgium, and in most industrialized countries, high levels of partial resistance to penicillin are exceptional and most strains are sensitive or have low-levels of partial resistance. A high cure rate can still be obtained even with single, high doses of procaine penicillin combined with probenecid as described by Taylor and Seth (1975) in London. In cases of hypersensitivity to penicillin, many alternatives are available. The mixture of sulphamethoxazole with trimethoprim is strongly synergistic, and therapeutic results with this mixture were good (Lawrence, Phillips, and Nicol, 1973). As to the frequency distributions of the MICs of the different antibacterial agents tested, our results are comparable with those for other European countries (Phillips and others, 1970, Stolz, Zwart, and Michel, 1974); all Belgian strains are sensitive to $10 \mu \mathrm{g}$. or less per ml. of spectinomycin, compared with $95 \cdot 6$ per cent. in England (Porter and Wood, 1974) and 77.4 per cent. in Finland (Kousa, Lassus, Jarvelainen, and Renkonen, 1974). Gonococci most resistant to one antibiotic are most likely to show multiple resistance (Maier and others, 1974). Although we did not attempt to study this particularly, of the twenty strains highly resistant to streptomycin in our series, relative resistance was found in nineteen of these strains for penicillin (MIC $\geqq 0.048 \mu \mathrm{g} . / \mathrm{ml}$.), in eighteen strains for ampicillin (MIC $\geqq 0.1 \mu \mathrm{g} . / \mathrm{ml}$. ), and in sixteen for tetracycline (MIC $\geqq 1.56 \mu \mathrm{g} . / \mathrm{ml}$.). Based on product-moment correlations, Maness and Sparling (1973), also found a significant positive correlation between the sensitivities of any pair of penicillin, tetracycline, erythromycin, and streptomycin, except for the streptomycin-erythromycin; we found a significant positive correlation for these antibiotics and also for erythromycin and rifampicin. The significance level of the correlation with tetracycline is lower in our series than in the results of Maness and Sparling (1973); these authors found no correlation between sensitivities to spectinomycin and the other antibiotics, and this is supported by our results. This is an important argument in favour of the use of spectinomycin in cases in which treatment with penicillin or the other antibiotics has failed (Reyn, Schmidt, Trier, and Bentzon,
1973; Givan and Keyl, 1974; Meheus, de Brauwere, and Muganza, 1974).

Stolz, Zwart, and Michel (1975) calculated rank correlation coefficients between the MICs of penicillin, ampicillin rifampicin, tetracycline, spectinomycin, sulphamethoxazole, trimethoprim, and a combination of sulphamethoxazole and trimethoprim 5:1. Our results are comparable except that the correlation of penicillin and ampicillin with tetracycline is much lower in our series, and that we found a significant positive correlation for penicillin and ampicillin with the sulphamethoxazole-trimethoprim combination.

This study was supported by a grant from Merck, Sharp and Dohme, Belgium.

\section{References}

AmIEs, C. R. (1969) Brit. F. vener. Dis., 45, 216

ARYA, O. P., and PhIllips, I. (1970) Ibid., 46, 149

Givan, K. F., and KeYL, A. (1974) Canad. med. Ass. F., 111, 44

Hart, G. (1973) Med. F. Aust., 2, 638

Kousa, M., LASSUS, A., JärVELÄINEN, R., and RENKoneN, O.-V. (1974) Brit. f. vener. Dis., 50, 291

Lawrence, A., Phillips, I., and Nicol, C. (1973) $\mathcal{F}$. infect. Dis., 128, Suppl. p. 673.

MaIer, T. W., BeIlstein, H. R., and ZubRZYCKI, L. (1974) Antimicrob. Agents Chemother., 6, 22

, ZuBRZYCKI, L., and COYLE, M. B. (1975) Ibid., 7, 676

MANESS, M. J., and Sparling, P. F. (1973) f. infect. Dis., 128, 321

Martin, J. E., Lester, A., Price, E. V., and Schmale, J. D. (1970) Ibid., 122, 459

Meheus, A. Z., De Brauwere, D., and Muganza, F. (1974) Curr. Ther. Res., 16, 1091

Panikabutra, K., and Suvanmalik, S. (1973) Brit. F. vener. Dis., 49, 209

Phillips, I., Rimmer, D., Ridley, M., LynN, R., and WARREN, C. (1970) Lancet, 1, 263

PloRde, J. J., KidAN, T. G., and WRIGHT, L. J. (1973) Brit. F. vener Dis., 49, 260

PORTER, I. A., and WOOD, W. J. (1974) Ibid., 50, 289

REYN, A., and BENTZON, M. W. (1968) Ibid., 44, 140

- - (1969) Ibid., 45, 223

-, Schmidt, H., Trier, M., and Bentzon, M. W. (1973) Ibid., 49, 54

Sarubbi, F. A., Blackman, E., and Spariing, P. F. (1974) f. Bact., 120, 1284

SMITHURST, B. A. (1974) Med. F. Aust., 1, 585

Sparling, P. F. (1972) Med. Clin. N. Amer., 56, 1133

Stolz, E., ZwarT, H. G. F., and Michel, M. F. (1974) Brit. f. vener. Dis., 50, 202

,,$---(1975)$ Ibid., 51, 257

TAYLOR, P. K., and SETH, A. D. (1975) Ibid., 51, 183

ThaYer, J. D., and Martin, J. E. (1966) Publ. Hlth Rep. (Wash.), 81, 559

Watko, L. P., and Brownlow, W. J. (1975) Brit. F. vener. Dis., 51, 34 